\title{
Vibrio atlanticus sp. nov. and Vibrio artabrorum sp. nov., isolated from the clams Ruditapes philippinarum and Ruditapes decussatus
}

\author{
Correspondence \\ Jesús L. Romalde \\ jesus.romalde@usc.es
}

\author{
Ana L. Diéguez, ${ }^{1 \dagger}$ Roxana Beaz-Hidalgo, ${ }^{1+\ddagger}$ IIse Cleenwerck, ${ }^{2}$ \\ Sabela Balboa, ${ }^{1}$ Paul de Vos $^{2}$ and Jesús L. Romalde ${ }^{1}$
}

${ }^{1}$ Departamento de Microbiología y Parasitología, Facultad de Biología. Universidad de Santiago de
Compostela. 15782, Santiago de Compostela, Spain ${ }^{2}$ BCCM/LMG Bacteria Collection, Laboratory of Microbiology, Ghent University, Ghent, Belgium
Vibrios were one of the first groups of bacteria to be recognized in nature (Pacini, 1854). Their taxonomy has been studied in depth, and has been subjected to consecutive rearrangements as a result of the development and use of molecular techniques such as DNA-DNA hybridization, multilocus sequence analysis (MLSA) and amplified fragment length polymorphism (AFLP), among others (Colwell, 2006; Thompson \& Swings, 2006; BeazHidalgo et al., 2010). Moreover, the great abundance of vibrios in aquatic environments, the high diversity detected

†These authors contributed equally to this work.

łPresent address: Departamento de Ciencias Médicas Básicas. Universidad Rovira i Virgili, Reus, Spain.

Abbreviations: AFLP, amplified fragment length polymorphism; MALDITOF, matrix-assisted laser desorption/ionization time-of-flight; VP, Voges-Proskauer.

The GenBank/EMBL/DDBJ accession numbers for the 16S rRNA, recA, rpoA, rpoD, atpA and $p y r \mathrm{H}$ gene sequences of strain $\mathrm{Vb} 11.11^{\top}$ are EF599163, EU541589, EU541569, FN582265, FN582252 and FN582266, respectively. Those for the 16S rRNA, recA, rpoA, rpoD, atpA and pyr $\mathrm{H}$ gene sequences of strain $\mathrm{Vb} 11.8^{\top}$ are EF599164, EU541588, EU541568, FN668926, FN668898 and FN668929, respectively. Accession numbers for sequences of the other isolates studied are given in Supplementary Tables S1 and S2.

Seven supplementary tables and seven supplementary figures are available with the online version of this paper. among members of the family Vibrionaceae and the increasing number of environmental studies have significantly contributed to the description of novel species of the genus Vibrio (Austin et al., 1997; Beaz-Hidalgo et al., 2010). At the time of writing, more than 70 species are recognized, grouped in 14 clades (Sawabe et al., 2007). Among these, the Splendidus clade contains the highest number of species $(>10)$, which have been found to be the dominant Vibrio species in coastal marine sediments, seawater and bivalves in temperate climates (Lambert et al., 1998; Sobecky et al., 1998). Some of these species have been associated with mortality of a wide range of marine animals such as molluscs, crustaceans and fish (Kueh \& Chan, 1985; Pujalte et al., 1993; Nicolas et al., 1996; Leano et al., 1998; Sugumar et al., 1998; Lacoste et al., 2001; Le Roux et al., 2002; Waechter et al., 2002; Farto et al., 2003; Jensen et al., 2003; Gay et al., 2004; Gómez-León et al., 2005).

In a previous study, a collection of isolates tentatively allocated to the genus Vibrio based on their phenotypic features were analysed by AFLP. Two groups, cluster 5 and cluster 70, consisted of isolates that could not be assigned to any of the currently known species of the genus Vibrio (Beaz-Hidalgo et al., 2008). In this study, we report on the further taxonomic characterization of these two groups of isolates obtained from clams, Ruditapes philippinarum and Ruditapes decussatus, cultured in Galicia. 
Cluster 5 isolates [Vb $11.11^{\mathrm{T}}\left(=\mathrm{CECT} \quad 7223^{\mathrm{T}}=\mathrm{LMG}\right.$ $24300^{\mathrm{T}}$ ), C $14.7(=\mathrm{LMG} 25697), \mathrm{C} 2.4, \mathrm{C} 15.19$ and $\mathrm{Cmj}$ 13.4] and cluster 70 isolates [Vb $11.8^{\mathrm{T}}$ (=CECT $7226^{\mathrm{T}}$

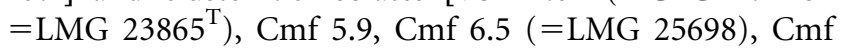
11.16, Rd 16.2, Rd 14.14, Rd 14.3 and C 15.18] were obtained from cultured clams on the north-west coast of Spain (Galicia) during a two-year survey from March 2004 to December 2005 as previously described (Beaz-Hidalgo et al., 2008). The type strains Vibrio gigantis LMG $22741^{\mathrm{T}}$, V. tasmaniensis LMG $20012^{\mathrm{T}}$, V. kanaloae LMG $20539^{\mathrm{T}}$, V. cyclitrophicus LMG $21359^{\mathrm{T}}$, V. crassostreae LMG $22240^{\mathrm{T}}$, V. pomeroyi LMG $20537^{\mathrm{T}}$, V. splendidus LMG $19031^{\mathrm{T}}, V$. lentus CECT $5110^{\mathrm{T}}$, V. gallaecicus LMG $24045^{\mathrm{T}}(=\mathrm{CECT}$ $7244^{\mathrm{T}}$ ) and V. chagasii LMG $21353^{\mathrm{T}}$ were obtained from the BCCM/LMG collection and included in the study for taxonomic comparison. All strains were cultured on marine agar (MA, Pronadisa) at $25{ }^{\circ} \mathrm{C}$ for $24 \mathrm{~h}$. Cultures were maintained frozen at $-80{ }^{\circ} \mathrm{C}$ in marine broth (MB, Pronadisa) supplemented with $15 \%(\mathrm{v} / \mathrm{v})$ glycerol.

Phenotypic characteristics were determined using standard methods and by commercial miniaturized kits (API 50CH, API 20E and API ZYM; bioMérieux). API 50CH was used with slight modifications as reported previously (BeazHidalgo et al., 2009). Briefly, bacterial suspensions were prepared in saline solution (SS; $0.85 \% \mathrm{NaCl}$ ), adjusted to an $\mathrm{OD}_{580}$ of 1.0 and mixed with ZOF medium (Lemos et al., 1985) $(1: 10, \mathrm{v} / \mathrm{v})$ prior to the inoculation of the galleries. Readings were taken at 24, 48, 96 and $120 \mathrm{~h}$ and after 6 days. Readings after 6 days of incubation were considered as the final result. For API 20E and API ZYM, standard methodologies were used except that the SS was used to prepare the bacterial suspensions. In all cases, incubation was done at $25{ }^{\circ} \mathrm{C}$. Routine phenotypic tests were performed following the methodologies described by Lemos et al. (1985), West et al. (1986), Romalde \& Toranzo (1991) and MacFaddin (1993). All media were supplemented with $1 \% \mathrm{NaCl}$ when required.

Genomic DNA for sequencing was extracted as described previously (Prado et al., 2005). Amplification and sequencing of the 16S rRNA gene were performed by using a GenomeLab DTCS-Quick Start kit (Beckman Coulter). Amplification and sequencing of the housekeeping genes $r p o A, r e c A$, atpA, pyrH and $r p o D$ were performed according to Thompson et al. $(2004,2005,2007)$. Accession numbers for sequences of the isolates studied are given in Supplementary Tables S1 and S2 (available in IJSEM Online). For reference strains, sequences were retrieved from GenBank/ EMBL/DDBJ. Sequence data analysis was performed with the DNASTAR Lasergene SEQMAN program. Sequences of the isolates were subjected to a BLAST search against the latest release of GenBank. Phylogenetic trees were reconstructed using the neighbour-joining and maximum-likelihood algorithms (Tamura et al., 2007; Posada, 2008; FigTree v1.1.2, http://tree.bio.ed.ac.uk/). Distance matrices were calculated using Kimura's two-parameter correction. Stability of the groupings was estimated by bootstrap analysis (1000 replicates) using the program MEGA version 4.0 (Tamura et al., 2007). If needed, putative recombination events were detected using RDP3 Beta 41 (Martin et al., 2005).

All strains of both clusters were facultatively anaerobic, Gram-negative, and oxidase and catalase-positive. All isolates from cluster 5 were motile, but in cluster 70 only three out of eight isolates showed this characteristic. They required salt for growth, grew on thiosulfate-citrate-bilesucrose agar (TCBS, Oxoid), reduced nitrates to nitrites, and were able to grow at $4{ }^{\circ} \mathrm{C}$; features typical for vibrios. Phylogenetic analysis based on 16S rRNA gene sequences confirmed that the isolates belonged to the genus Vibrio. They were found to be related to species of the Splendidus clade (Supplementary Figs S1 and S2). Isolate Vb $11.11^{\mathrm{T}}$ (cluster 5) showed highest sequence similarities with the species $V$. tasmaniensis $(99.3 \%), V$. lentus $(99.1 \%)$ and $V$. splendidus (99.0\%) (Supplementary Table S3), whereas $V$. gigantis $(99.9 \%), V$. pomeroyi $(99.4 \%), V$. crassostreae $(99.5 \%), V$. tasmaniensis $(99.2 \%)$ and $V$. splendidus $(99.0 \%)$ were the closest relatives of isolate $\mathrm{Vb} 11.8^{\mathrm{T}}$ (cluster 70) (Supplementary Table S4).

Sequence analysis of housekeeping genes has proven to be a useful tool to infer phylogenetic relationships among micro-organisms. For the family Vibrionaceae, different loci, including gyrB, recA, rpoA, pyrH, atpA and dnaJ, have been studied in the search for a phylogenetic marker capable of delineating species of the genus Vibrio (Thompson et al., 2004, 2005, 2007; Sawabe et al., 2007; Nhung et al., 2007; Pascual et al., 2010). In the present study, sequences of the genes recA (613-713 bp), rpoA (931 bp), pyrH (443 bp), atpA (1322 bp) and rpoD (780 bp) were obtained for the clam isolates and compared with those of related species (Supplementary Tables S3 and S4). Based on the housekeeping gene sequences analysed, with the exception of the rpoD and atpA genes, $V$. tasmaniensis appeared to be the closest relative of the cluster 5 isolates (Supplementary Table S3), with similarity values higher than the interspecies limit previously described (Thompson et al., 2005). However, the inaccuracy of these limits has been pointed out recently by Pascual et al. (2010) for species belonging to the central clade of the genus Vibrio. In addition, within cluster 5 isolates, recombination events have been detected in the pyrH and recA genes for strains C 15.19 and C 14.17, respectively. These recombination events affect the trees' topologies (Supplementary Fig. S3). In the case of the cluster 70 isolates, each housekeeping gene pointed a different species of the genus Vibrio as the closest relative (i.e. Vibrio kanaloae with recA or Vibrio pomeroyi with rpoA) (Supplementary Table S4 and Supplementary Fig. S4). Phylogenetic trees based on concatenated sequences of the $16 \mathrm{~S}$ rRNA, rpoA, recA, pyrH, atpA and $r p o D$ genes confirmed the allocation of the isolates in the Splendidus clade, also enabling their differentiation from the recognized species of the clade (Figs 1 and 2, Supplementary Figs S5 and S6). 


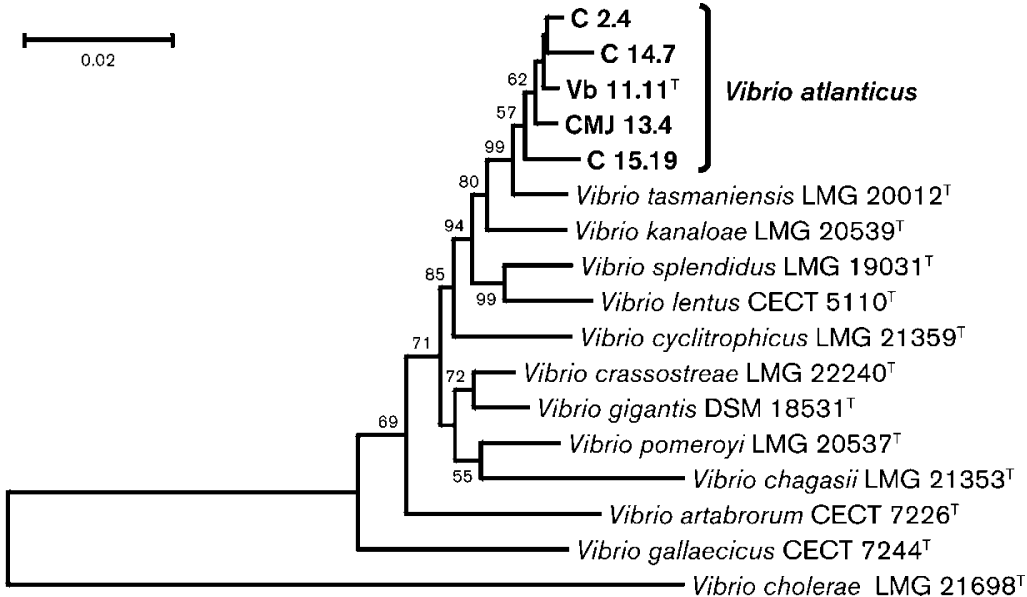

Fig. 1. Neighbour-joining tree showing the phylogenetic position of the cluster 5 strains, based on concatenated sequences of the four housekeeping genes $\operatorname{rec} A, r p o A, r p o D$ and atp $A$, and the $16 \mathrm{~S}$ rRNA gene. Vibrio cholerae was used as the outgroup. The stability of the grouping was estimated by bootstrap percentages from 1000 replicates. Similar results were obtained with the maximum-likelihood algorithm. Bar, 0.02 substitutions per nucleotide position. Numbers at nodes show percentage bootstrap values.
Genomic DNA for DNA-DNA hybridization experiments and DNA G $+\mathrm{C}$ content determinations was extracted as previously described (Cleenwerck et al., 2002). DNA-DNA hybridizations between strains $\mathrm{Vb} 11.11^{\mathrm{T}}, \mathrm{Vb} 11.8^{\mathrm{T}}$ and the type strains of the known species of the Splendidus clade were performed at $39{ }^{\circ} \mathrm{C}$ in a hybridization solution containing $50 \%$ formamide, according to a modification (Goris et al., 1998) of the microplate method described by Ezaki et al. (1989). Reciprocal reactions (i.e. $\mathrm{A} \times \mathrm{B}$ and $\mathrm{B} \times \mathrm{A}$ ) were performed and were generally within the limits of this method (Goris et al., 1998). DNA-DNA relatedness values (\%) reported are based on a minimum of four hybridizations. Additional reactions, namely those between strains $\mathrm{Vb} 11.11^{\mathrm{T}}$ and $\mathrm{Vb} 11.8^{\mathrm{T}}$ and against the other strains in their respective clusters, were performed by the hydroxyapatite/microtitre plate method (Ziemke et al., $1998)$ with a hybridization temperature $\left(T_{\mathrm{m}}\right)$ of $60{ }^{\circ} \mathrm{C}$. The DNA G $+\mathrm{C}$ contents were determined using HPLC as previously described (Mesbah et al. 1989).
The DNA G $+\mathrm{C}$ content of strain $\mathrm{Vb} 11.11^{\mathrm{T}}$ was $44.2 \%$ and of strain $\mathrm{Vb} 11.8^{\mathrm{T}}$ was $44.4 \%$, which is within the range of DNA G $+C$ content reported for species of the genus Vibrio. DNA-DNA relatedness values for strains $\mathrm{Vb} 11.11^{\mathrm{T}}$ (cluster 5 ) and $\mathrm{Vb} 11.8^{\mathrm{T}}$ (cluster 70 ) and the type strains of the Splendidus clade tested were always below $70 \%$ (Supplementary Table S5). DNA-DNA relatedness values between strain $\mathrm{Vb} 11.11^{\mathrm{T}}$ and the other isolates of cluster 5 ranged from 78 to $94 \%$, and between strain $\mathrm{Vb} 11.8^{\mathrm{T}}$ and the rest of the isolates of cluster 70 fluctuated between 81 and $95 \%$. The DNADNA relatedness value between strains $\mathrm{Vb} 11.11^{\mathrm{T}}$ and $\mathrm{Vb}$ $11.8^{\mathrm{T}}$ was $38 \%$. The DNA-DNA hybridization data demonstrated that the isolates belong to two novel species of the genus Vibrio.

Protein analysis by matrix-assisted laser desorption/ionization time-of-flight (MALDI-TOF) MS was performed in the mass unit of the University of Santiago de Compostela. Protein extraction was performed with ethanol, formic

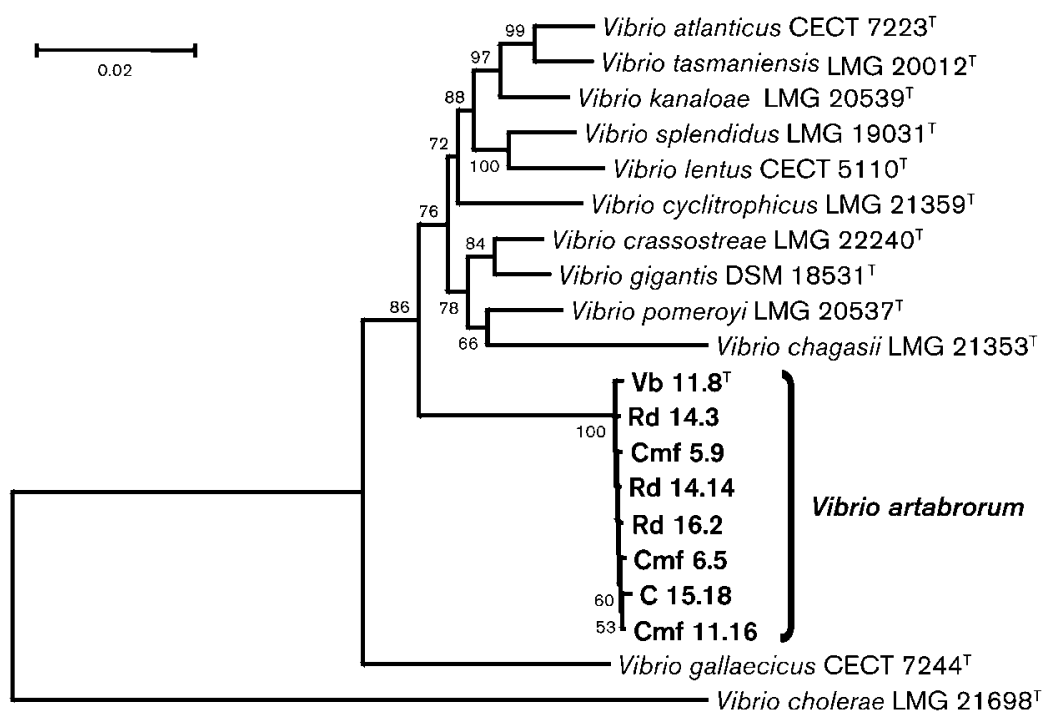

Fig. 2. Neighbour-joining tree showing the phylogenetic position of the cluster 70 strains, based on concatenated sequences of the five housekeeping genes $r e c A, p y r H, r p o A, r p o D$ and $\operatorname{atp} A$, and the $16 \mathrm{~S}$ rRNA gene. Vibrio cholerae was used as the outgroup. The stability of the groupings was estimated by bootstrap percentages from 1000 replicates. Similar results were obtained with the maximum-likelihood algorithm. Bar, 0.02 substitutions per nucleotide position. Numbers at nodes show percentage bootstrap values. 
acid and acetonitrile. Processed samples were placed in a 96-well plate, allowed to dry and covered with a matrix solution ( $\alpha$-cyano-4-hydroxycinnamic acid; HCCA). Mass spectra were obtained using a MALDI-TOF Autoflex mass spectrometer (Bruker Daltonik $\mathrm{GmbH}$ ). The measured spectra mass range was 2000-20000 Da. Peak comparison was carried out with the database of Bruker Daltonik (http://clinprot.dbal.de). The species-limit value considered was 2300. Identification to the genus level was in the range 1700-1999. As a positive control, Escherichia coli CECT 433 was included in the analysis and protein profiles were compared with previously obtained profiles. Strains $\mathrm{Vb} 11.11^{\mathrm{T}}$ and $\mathrm{Vb} 11.8^{\mathrm{T}}$ showed unique protein profiles (Supplementary Fig. S7). The closest species in both cases was V. gigantis, with similarity values of 2187 and 2093, respectively.

The novel isolates can be differentiated from the phylogenetically related species of the genus Vibrio by several phenotypic features (Table 1). Strains of both clusters can be differentiated from $V$. splendidus by their positive reaction in the Voges-Proskauer (VP) test and their ability to grow with $6 \% \mathrm{NaCl}$. Strains of cluster 5 can be differentiated from $V$. tasmaniensis by their ability to produce acid from sucrose, hydrolyse Tween 80 , and use Dalanine as sole carbon source, and their inability to grow at $35{ }^{\circ} \mathrm{C}$. These strains can be differentiated from $V$. kanaloae by their positive reaction in the VP test and their negative reaction for the arginine dihydrolase test, and from $V$. cyclitrophicus by their inability to grow at $35{ }^{\circ} \mathrm{C}$ and with
$8 \% \mathrm{NaCl}$, as well as by their positive reaction for the VP test. Strains of cluster 70 can be differentiated from $V$. kanaloae and V. pomeroyi by their positive result in the VP test, and their inability to hydrolyse gelatin. In addition, the inability to hydrolyse Tween 80 or to use D-alanine as sole carbon source are also differential characteristics from V. kanaloae. Strains of cluster 70 can be differentiated from V. cyclitrophicus by their positive reaction to the VP test, and their inability to grow at $35{ }^{\circ} \mathrm{C}$ and hydrolyse gelatin and Tween 80 . Supplementary Tables S6 and S7 provide the intraspecific differences of the two clusters.

In conclusion, the molecular and phenotypic data presented above show clearly that the cluster 5 and cluster 70 isolates belong to two novel species in the Splendidus clade. The names Vibrio atlanticus sp. nov. and Vibrio artabrorum sp. nov. are proposed for these novel species.

\section{Description of Vibrio atlanticus sp. nov.}

Vibrio atlanticus (at.lan'ti.cus. L. masc. adj. atlanticus Atlantic, from the Atlantic Ocean).

Gram-negative, facultatively anaerobic, motile, flagellated rods $(0.7-0.8 \times 1.1-1.4 \mu \mathrm{m}$ in size). Colonies are beige in colour, round and smooth on MA. Swarming is not observed. Colonies are $2-6 \mathrm{~mm}$ in diameter on MA plates after $24 \mathrm{~h}$ of incubation at $25{ }^{\circ} \mathrm{C}$. Not luminescent. Oxidase- and catalase-positive. Negative for arginine dihydrolase, and lysine and ornithine decarboxylases. Reduces nitrate to nitrite. Voges-Proskauer test is positive

Table 1. Phenotypic characteristics for distinguishing $V$. atlanticus sp. nov. and $V$. artabrorum sp. nov. from phenotypically and phylogenetically related species of the genus Vibrio

Taxa: 1, V. atlanticus sp. nov. (five strains); 2, V. artabrorum sp. nov. (eight strains); 3, V. celticus CECT $7224^{\mathrm{T}} ; 4$. V. gigantis DSM 18531 ${ }^{\mathrm{T}}$; 5 , V. splendidus CECT 528 ${ }^{\mathrm{T}}$; 6, V. crassostreae LMG $22240^{\mathrm{T}}$; 7, V. pomeroyi LMG 20537 ${ }^{\mathrm{T}}$; 8, V. tasmaniensis LMG 20012 ${ }^{\mathrm{T}}$; 9, V. lentus CECT 5110 ${ }^{\mathrm{T}}$; 10 , V. kanaloae LMG 20539 ${ }^{\mathrm{T}}$; 11, V. chagasii LMG 21353 ${ }^{\mathrm{T}}$; 12, V. cyclitrophicus LMG 21359 ; 13, V. gallaecicus LMG $24045^{\mathrm{T}}$. Differential tests were performed in the laboratory on all $V$. atlanticus sp. nov. and $V$. artabrorum sp. nov. isolates as well as the type strains of the other vibrios within the Splendidus clade, using classical tube and plate methods and API 20E strips. +, Positive; -, negative; v, variable; $\mathrm{v}+$, variable but type strain is positive; $\mathrm{v}-$, variable but type strain is negative. The number of strains giving a positive result is indicated in parentheses.

\begin{tabular}{|c|c|c|c|c|c|c|c|c|c|c|c|c|c|}
\hline Characteristic & 1 & 2 & 3 & 4 & 5 & 6 & 7 & 8 & 9 & 10 & 11 & 12 & 13 \\
\hline ONPG & $v+(3)$ & $\mathrm{v}+(4)$ & - & - & + & - & + & - & + & - & - & + & - \\
\hline \multicolumn{14}{|l|}{ Acid from: } \\
\hline Sucrose & + & + & - & - & + & + & + & - & - & + & - & + & - \\
\hline L-Arabinose & $\mathrm{V}+(1)$ & $v+(4)$ & - & - & - & - & + & - & - & - & - & - & - \\
\hline \multicolumn{14}{|l|}{ Growth at/with: } \\
\hline $35^{\circ} \mathrm{C}$ & - & $\mathrm{V}-(1)$ & - & - & - & - & - & + & - & - & - & + & - \\
\hline $6 \% \mathrm{NaCl}$ & + & + & + & - & - & + & + & + & + & + & + & + & - \\
\hline $8 \% \mathrm{NaCl}$ & - & $\mathrm{V}-(1)$ & - & - & - & - & + & - & - & - & + & + & - \\
\hline \multicolumn{14}{|l|}{ Hydrolysis of: } \\
\hline Gelatin & $\mathrm{V}-(4)$ & - & + & + & + & + & + & - & + & + & + & + & + \\
\hline
\end{tabular}


and indole test is usually positive. All strains hydrolyse starch and Tween 80 . Gelatin is hydrolysed by all isolates except the type strain, $\mathrm{Vb} 11.11^{\mathrm{T}}$. Growth occurs at $4{ }^{\circ} \mathrm{C}$ and with $3-6 \% \mathrm{NaCl}(\mathrm{w} / \mathrm{v})$, but not at 3 or $44{ }^{\circ} \mathrm{C}$ and salinities greater than $8 \% \mathrm{NaCl}$. Most strains are susceptible to the vibriostatic agent $\mathrm{O} / 129(150 \mu \mathrm{g}$ per disc). Acid is produced from glycerol, D-ribose, D-glucose, D-fructose, D-mannose, $\mathrm{N}$-acetylglucosamine, aesculin, cellobiose, maltose, trehalose, starch, glycogen and potassium gluconate. None of the strains produce acid from erythritol, D-arabinose, L-xylose, D-adonitol, methyl $\beta$-Dxylopyranoside, L-sorbose, L-rhamnose, dulcitol, inositol, D-sorbitol, methyl $\alpha$-D-mannopyranoside, methyl $\alpha$-Dglucopyranoside, amygdalin, arbutin, salicin, melibiose, inulin, melezitose, raffinose, xylitol, turanose, D-lyxose, Dfucose, D-arabitol, L-arabitol, potassium 2-ketogluconate or potassium 5-ketogluconate. In addition, the type strain, $\mathrm{Vb} 11.11^{\mathrm{T}}$, produced acid from L-arabinose, D-xylose, sucrose, D-galactose, D-mannitol, gentiobiose and L-fucose. All strains can use as sole carbon source D-ribose, Dfructose, trehalose, maltose, cellobiose, sucrose, gluconic acid, D-mannitol, glycerol, succinic acid, L-threonine, Lglutamic acid, D-alanine, L-arginine and L-tyrosine, but not D-xylose, L-rhamnose, lactose, D-salicin, D-amygdalin, Dsorbitol, myo-inositol, butyric acid, L-ornithine, amino- $N$ butyric acid, L-lysine, putrescine, 3-hydroxybutyric acid or $\mathrm{L}$-fucose. In addition, the type strain, $\mathrm{Vb} 11.11^{\mathrm{T}}$, can use as sole carbon source D-glucose, sodium acetate, propionic acid, citric acid, L-serine, L-citrulline, aspartic acid and Lhistidine.

The type strain, $\mathrm{Vb} 11.11^{\mathrm{T}} \quad\left(=\mathrm{CECT} \quad 7223^{\mathrm{T}}=\mathrm{LMG}\right.$ $\left.24300^{\mathrm{T}}\right)$, was isolated from clam, Ruditapes philippinarum, in Galicia, north-west Spain, in January 2005. The DNA $\mathrm{G}+\mathrm{C}$ content of strain $\mathrm{Vb} 11.11^{\mathrm{T}}$ is $44.2 \mathrm{~mol} \%$.

\section{Description of Vibrio artabrorum sp. nov.}

Vibrio artabrorum [ar.ta.bro'rum. L. gen. pl. n. artabrorum intended to mean that this species was isolated from 'Portus Magnus Artabrorum' (the largest harbour of the Artabri), the Latin name of the main gulf in the Galician coasts].

Gram-negative, facultatively anaerobic rods $(0.8-1.0 \times 1.4-$ $1.8 \mu \mathrm{m}$ in size). On MA plates after $24 \mathrm{~h}$ of incubation at $25{ }^{\circ} \mathrm{C}$, non-swarming, beige, round and smooth $2-6 \mathrm{~mm}$ diameter colonies are observed. Strain $\mathrm{Cmf} 6.5$ produces a brownish diffusible pigment. Not luminescent. All isolates form yellow colonies on TCBS agar. Growth occurs with 3$6 \% \mathrm{NaCl}(\mathrm{w} / \mathrm{v})$ (one isolate is able to grow in media with $0.5-8 \% \mathrm{NaCl}$ ). Growth occurs at $4{ }^{\circ} \mathrm{C}$, but not at $35{ }^{\circ} \mathrm{C}$ (one exception). Mostly susceptible to the vibriostatic agent $\mathrm{O} / 129$ (150 $\mu \mathrm{g}$ per disc). All isolates are positive for oxidase and catalase and reduce nitrates to nitrites. VogesProskauer test is positive, but lysine and ornithine decarboxylase, indole, gelatinase and lipase tests are negative. All strains produce acid from D-ribose, Dgalactose, D-fructose, D-mannose, D-mannitol, $\mathrm{N}$-acetylglucosamine, cellobiose, maltose, sucrose, trehalose, starch, glycogen and potassium gluconate. None of the strains produce acid from erythritol, L-xylose, D-adonitol, methyl $\beta$-D-xylopyranoside, L-sorbose, inositol, D-sorbitol, methyl $\alpha$-D-mannopyranoside, amygdalin, salicin, inulin, melezitose, raffinose, xylitol, D-fucose, L-arabitol or potassium 5ketogluconate. The type strain, $\mathrm{Vb} 11.8^{\mathrm{T}}$, also produced acid from glycerol, L-arabinose, D-xylose and D-rhamnose. All isolates can use as sole carbon source D-ribose, Dfructose, trehalose, D-mannose, maltose, cellobiose, sucrose, gluconic acid, glucuronic acid, D-mannitol, glycerol, succinic acid, L-arginine, L-citrulline and aspartic acid, but not L-rhamnose, salicin, amygdalin, D-sorbitol, myoinositol, butyric acid, L-ornithine, amino- $\mathrm{N}$-butyric acid, L-lysine, putrescine or 3-hydroxybutyric acid. The type strain, $\mathrm{Vb} 11.8^{\mathrm{T}}$, can also use as sole carbon source $\mathrm{D}-$ xylose, D-glucose, D-galactose, galacturonic acid, sodium acetate, threonine and $\alpha$-ketoglutaric acid.

The type strain, $\mathrm{Vb} 11.8^{\mathrm{T}}\left(=\right.$ CECT $7226^{\mathrm{T}}=$ LMG $\left.23865^{\mathrm{T}}\right)$, was isolated from clam, Ruditapes philippinarum, in Galicia, north-west Spain, in January 2005. The DNA $\mathrm{G}+\mathrm{C}$ content of strain $\mathrm{Vb} 11.8^{\mathrm{T}}$ is $44.4 \mathrm{~mol} \%$.

\section{Acknowledgements}

This work was supported in part by grants from the Ministerio de Ciencia y Tecnología (AGL2003-09307-C02-01 and AGL2006-13208C02-01) and Xunta de Galicia (Spain) (PGIDIT04PXIC20001PN). S. B. acknowledges the Ministerio de Ciencia y Tecnología (Spain) for a research fellowship. The authors thank E. Guitian from the RIAIDT (USC) for mass spectrometry analysis and Bruker Daltonik GmbH for database availability. The research was also supported by the Prime Minister's Services, Federal Office for Scientific, Technical and Culture Affairs, Belgium. The authors wish to thank Katrien Engelbeen for performing the DNA-DNA hybridizations.

\section{References}

Austin, B., Austin, D. A., Blanch, A. R., Cerda, M., Grimont, P. A. D., Jofre, J., Koblavi, S., Larsen, J. L., Pedersen, K. \& other authors (1997). A comparison of methods for the typing of fish-pathogenic Vibrio spp. Syst Appl Microbiol 20, 89-101.

Beaz-Hidalgo, R., Cleenwerck, I., Balboa, S., De Wachter, M., Thompson, F. L., Swings, J., De Vos, P. \& Romalde, J. L. (2008). Diversity of Vibrios associated with reared clams in Galicia (NW Spain). Syst Appl Microbiol 31, 215-222.

Beaz-Hidalgo, R., Doce, A., Pascual, J., Toranzo, A. E. \& Romalde, J. L. (2009). Vibrio gallaecicus sp. nov. isolated from cultured clams in north-western Spain. Syst Appl Microbiol 32, 111-117.

Beaz-Hidalgo, R., Balboa, S., Romalde, J. L. \& Figueras, M. J. (2010). Diversity and pathogenicity of Vibrio species in cultured bivalve molluscs. Environ Microbiol Reports 2, 34-43.

Cleenwerck, I., Vandemeulebroecke, K., Janssens, D. \& Swings, J. (2002). Re-examination of the genus Acetobacter, with descriptions of Acetobacter cerevisiae sp. nov. and Acetobacter malorum sp. nov. Int J Syst Evol Microbiol 52, 1551-1558.

Colwell, R. R. (2006). A global and historical perspective of the genus Vibrio. In The Biology of Vibrios, pp. 3-11. Edited by F. L. Thompson, B. Austin \& J. Swings. Washington, DC: American Society for Microbiology. 
Ezaki, T., Hashimoto, Y. \& Yabuuchi, E. (1989). Fluorometric deoxyribonucleic acid-deoxyribonucleic acid hybridization in microdilution wells as an alternative to membrane filter hybridization in which radioisotopes are used to determine genetic relatedness among bacterial strains. Int J Syst Bacteriol 39, 224-229.

Farto, R., Armada, S. P., Montes, M., Guisande, J. A., Pérez, M. J. \& Nieto, T. P. (2003). Vibrio lentus associated with diseased wild octopus (Octopus vulgaris). J Invertebr Pathol 83, 149-156.

Gay, M., Renault, T., Pons, A. M. \& Le Roux, F. (2004). Two Vibrio splendidus related strains collaborate to kill Crassostrea gigas: taxonomy and host alterations. Dis Aquat Organ 62, 65-74.

Gómez-León, J., Villamil, L., Lemos, M. L., Novoa, B. \& Figueras, A. (2005). Isolation of Vibrio alginolyticus and Vibrio splendidus from aquacultured carpet shell clam (Ruditapes decussatus) larvae associated with mass mortalities. Appl Environ Microbiol 71, 98-104.

Goris, J., Suzuki, K., de Vos, P., Nakase, T. \& Kersters, K. (1998). Evaluation of a microplate DNA-DNA hybridization method compared with the initial renaturation method. Can J Microbiol 44, 1148-1153.

Jensen, S., Samuelsen, O. B., Andersen, K., Torkildsen, L., Lambert, C., Choquet, G., Paillard, C. \& Bergh, O. (2003). Characterization of strains of Vibrio splendidus and $V$. tapetis isolated from corkwing wrasse Symphodus melops suffering vibriosis. Dis Aquat Organ $\mathbf{5 3}$ 25-31.

Kueh, C. S. W. \& Chan, K. Y. (1985). Bacteria in bivalve shellfish with special reference to the oyster. J Appl Bacteriol 59, 41-47.

Lacoste, A., Jalabert, F., Malham, S., Cueff, A., Gélébart, F., Cordevant, C., Lange, M. \& Poulet, S. A. (2001). A Vibrio splendidus strain is associated with summer mortality of juvenile oysters Crassostrea gigas in the Bay of Morlaix (North Brittany, France). Dis Aquat Organ 46, 139-145.

Lambert, C., Nicolas, J. L., Cilia, V. \& Corre, S. (1998). Vibrio pectenicida sp. nov., a pathogen of scallop (Pecten maximus) larvae. Int J Syst Bacteriol 48, 481-487.

Le Roux, F., Gay, M., Lambert, C., Waechter, M., Poubalanne, S., Chollet, B., Nicolas, J. L. \& Berthe, F. C. J. (2002). Comparative analysis of Vibrio splendidus-related strains isolated during Crassostreae gigas mortality events. Aquat Living Resour 15, 251-258.

Leano, E. M., Lavilla-Pitogo, C. R. \& Paner, M. G. (1998). Bacterial flora in the hepatopancreas of pond reared Penaeus monodon juveniles with luminous vibriosis. Aquaculture 164, 367-374.

Lemos, M. L., Toranzo, A. E. \& Barja, J. L. (1985). Modified medium for the oxidation-fermentation test in the identification of marine bacteria. Appl Environ Microbiol 49, 1541-1543.

MacFaddin, J. F. (1993). Pruebas Bioquímicas para la Identificación de Bacterias de Importancia Clínica (translation by Médica Panamericana SA). Baltimore, MD: Williams \& Wilkins (in Spanish).

Martin, D. P., Williamson, C. \& Posada, D. (2005). RDP2: recombination detection and analysis from sequence alignments. Bioinformatics 21, 260-262.

Mesbah, M., Premachandran, U. \& Whitman, W. B. (1989). Precise measurement of the $\mathrm{G}+\mathrm{C}$ content of deoxyribonucleic acid by high performance liquid chromatography. Int J Syst Bacteriol 39, 159-167.

Nhung, P. H., Shah, M. M., Ohkusu, K., Noda, M., Hata, H., Sun, X. S., lihara, H., Goto, K., Masaki, T. \& Miyasaka, J. (2007). The dnaJ gene as a novel phylogenetic marker for identification of Vibrio species. Syst Appl Microbiol 30, 309-315.
Nicolas, J. L., Corre, S., Gauthier, G., Robert, R. \& Ansquer, D. (1996). Bacterial problems associated with scallop Pecten maximus larval culture. Dis Aquat Organ 27, 67-76.

Pacini, F. (1854). Osservazione microscopiche e deduzione patologiche sul colera asiatico. Gaz Med Italiana 6, 405-412.

Pascual, J., Macián, M. C., Arahal, D. R., Garay, E. \& Pujalte, M. J. (2010). Multilocus sequence analysis of the central clade of the genus Vibrio by using the $16 \mathrm{~S} r \mathrm{RNA}, r e c \mathrm{~A}, p y r \mathrm{H}, r p o \mathrm{D}, g y r \mathrm{~B}, r c t \mathrm{~B}$ and tox $\mathrm{R}$ genes. Int J Syst Evol Microbiol 60, 154-165.

Posada, D. (2008). jModelTest: phylogenetic model averaging. Mol Biol Evol 25, 1253-1256.

Prado, S., Romalde, J. L., Montes, J. \& Barja, J. L. (2005). Pathogenic bacteria isolated from disease outbreaks in shellfish hatcheries. First description of Vibrio neptunius as an oyster pathogen. Dis Aquat Organ 67, 209-215.

Pujalte, M. J., Ortigosa, M., Urdaci, M. C., Garay, E. \& Grimont, P. A. D. (1993). Vibrio mytili sp. nov., from mussels. Int J Syst Bacteriol 43, 358-362.

Romalde, J. L. \& Toranzo, A. E. (1991). Evaluation of the API 20E system for the routine diagnosis of the enteric redmouth disease. Bull Eur Assoc Fish Pathol 11, 147-149.

Sawabe, T., Kita-Tsukamoto, K. \& Thompson, F. L. (2007). Inferring the evolutionary history of vibrios by means of multilocus sequence analysis. J Bacteriol 189, 7932-7936.

Sobecky, P. A., Mincer, T. J., Chang, M. C., Toukdarian, A. \& Helinski, D. R. (1998). Isolation of broad-host-range replicons from marine sediment bacteria. Appl Environ Microbiol 64, 2822-2830.

Sugumar, G., Nakai, T., Hirata, Y., Matsubara, D. \& Muroga, K. (1998). Vibrio splendidus biovar II as the causative agent of bacillary necrosis of Japanese oyster Crassostrea gigas larvae. Dis Aquat Organ 33, 111-118.

Tamura, K., Dudley, J., Nei, M. \& Kumar, S. (2007). MEGA4: molecular evolutionary genetics analysis (MEGA) software version 4.0. Mol Biol Evol 24, 1596-1599.

Thompson, F. L. \& Swings, J. (2006). Taxonomy of the vibrios. In The Biology of Vibrios, pp. 29-43. Edited by F. L. Thompson, B. Austin \& J. Swings. Washington, DC: American Society for Microbiology.

Thompson, C. C., Thompson, F. L., Vandemeulebroecke, K., Hoste, B., Dawyndt, P. \& Swings, J. (2004). Use of $\operatorname{rec} A$ as an alternative phylogenetic marker in the family Vibrionaceae. Int J Syst Evol Microbiol 54, 919-924.

Thompson, F. L., Gevers, D., Thompson, C. C., Dawyndt, P., Naser, S., Hoste, B., Munn, C. B. \& Swings, J. (2005). Phylogeny and molecular identification of vibrios on the basis of multilocus sequence analysis. Appl Environ Microbiol 71, 5107-5115.

Thompson, C. C., Thompson, F. L., Vicente, A. C. \& Swings, J. (2007). Phylogenetic analysis of vibrios and related species by means of atpA gene sequences. Int J Syst Evol Microbiol 57, 2480-2484.

Waechter, M., Le Roux, F., Nicolas, J. L., Marissal, E. \& Berthe, F. (2002). [Characterization of pathogenic bacteria of the cupped oyster Crassostrea gigas]. C R Biol 325, 231-238 (in French).

West, P. A., Brayton, P. R., Bryant, T. N. \& Colwell, R. R. (1986). Numerical taxonomy of vibrios isolated from aquatic environments. Int J Syst Bacteriol 36, 531-543.

Ziemke, F., Höfle, M. G., Lalucat, J. \& Rosselló-Mora, R. (1998). Reclassification of Shewanella putrefaciens Owen's genomic group II as Shewanella baltica sp. nov. Int J Syst Bacteriol 48, 179-186. 